\title{
Resource-Deficient Regions: The Specificity of State Support
}

\author{
Ekaterina Sorokina ${ }^{+}$ \\ Department of Regional, Municipal Economy and Management, Ural State University of Economics, \\ Ekaterinburg, Russian Federation
}

\begin{abstract}
The success of Russia's socio-economic development heavily depends on resource availability, resource sufficiency, and resource diversity. Because economic resources (natural, human, capital, information, and material) represent a key barrier to regional social and economic development, the regionalfederal systems should take into account the effects of regional development drivers. This study aims to assess the level of economic development across economic regions in Russia regarding resource availability and develop state regulation measures to improve regional economic performance. For this, all regions were divided into groups by their gross regional product estimates. Factors reflecting economic performance were identified throughfactor analysis, and the cyclical nature of resources a vailability was discussed. The paper offers a resources availability model that allows determining the minimum a mount of resources requiredfor a region having a specific levelof economic development to achieve the maximum economic performance possible in less time. In addition, the paper presents a state regulatory framework for a regional economy that integrates financial support measures, state projects and programs, and mea sures to modify the regulatory framework and the regulation of human resources. The proposed sta te re g ulation framework takes into account the full range of regional resources and makes it possible to choose the mo st effective tools with the view to meeting regional development goals.
\end{abstract}

Keywords: Effectiveness, regional growth resource availa bility, regulation, state support.

JEL Codes: R10, R11, R15

\section{Introduction}

Ensuring resource security in the regions is a public relations effort and a process by which developed countries prevent excessive disparities in levels of the social and economic wellbeing of the regions. To ensure resource security, federal and regional authorities need to build favorable conditions, in particular through integration and cooperation between and within regions.

Modern Russia is characterized by scarcity of specific resources, on the one hand, and growing independence of economic regions, on the other hand. The natural resources deficit received a great deal of attention. Xinchun et al. (2017), for example, focused on water scarcity and measured the ratio of the total agricultural water footprint to water resources availability. The results showed a need for reducing the water load. Koliousis et al. (2018) drew their attention to industrial clusters, the key drivers of regional development. Similar studies were done by Odhiambo (2017), da Silva et al. (2018), Murshed and Kaluarachchi (2018), and Soula et al. (2021).

At the same time, there is no comprehensive study of the regional resource potential and its effect on economic growth. Given the socio-economic differences between economic regions, the Russian government needs a special strategy for allocating resources to innovation and development projects. The majority of scholars focused on exploring separate instruments of state regulation of the regional economy (Skokov, 
ISSN: 2247-6172

Review of Applied Socio- Economic Research

(Volume 22, Issue 2/ 2021),pp. 128 - 141

URL: http://www.reaser.eu

e-mail: editors@reaser.eu

2020). Analyzing market instruments, Tiutiunyk (2018) concentrated on financial tools, and Tamov et al. (2020) investigated the features of strategic development. It is worth noting that the state regulation strategy and tactics cannot appear out of thin air and require regular adjustments to meet social, economic, and organizational issues, most of which rely on state assistance (Abrosimova et al., 2021; Shohin et al., 2020). In this context, the key challenge is to develop methods and approaches for determining potentially favorable conditions for innovative resources generation and their application in regional economic development priority areas.

This study aims to assess the level of economic development across economic regions in Russia with regard to resources' availability and develop measures of state regulation to boost regions. The objectives of the study are to:

- determine the level of economic development across regions in Russia by looking at their GRPs (gross regional product);

- categorize economic regions by their levels of economic development;

- explore the supply of primary and secondary resources in the regions;

- substantiate the cyclical nature of resources generated in the region and the need for resource security measures;

- conduct a factor analysis with the view of exploring the relationship between economic growth and resources availability;

- develop instruments for state regulation to overcome natural resource scarcity across regions.

\section{Methods}

The level of regional economic development was evaluated through structuring, systematizing, and sorting statistical data on economic growth, i.e., via the gross regional product (GRP). The examined regions were divided into four groups according to their position in the GRP ranking.

Factors that affect the level of regional economic development were assessed by using socio-economic data from the Federal State Statistics Service (2019). In general, the present study distinguishes seven factors that shape the gross domestic product of a region (GRP). The influence of factors (independent variables) on the level of regional economic development (dependent variable) was identified through regression analysis.

The study hypothesizes that natural resources availability in a region undergoes fluctuations throughout different stages of regional development. This hypothesis was tested by modeling the law of regional development with the lifecycle method. There are eight region life cycle stages, each with its natural resources requirement. The present study proposes a number of state support measures to undertake in the event of resources scarcity at either of these stages.

The present study offers a mechanism of state influence to prevent resources scarcity in regions. The proposed model consists of three blocks: (1) factors that influence the development of state support measures; (2) a mechanism whereby external and internal factors influence the level of regional economic development; and (3) instruments and directions of state support to choose from depending on their availability and promises. 


\section{Results}

The economic substance of the region is largely understood from the economic theory perspective. The underlying assumptions about the examined economic regions and the principles of economic activity in these regions in the context of division of labor align with the economic theory.

In this study, a territory is regarded as an integral part of regional assets, a relatively independent economic entity that has specific resource potential and unique regional interests. These characteristics of regional/local economy add to the geographical and legal interpretations that describe the territory as a market and a community, among other things. Therefore, the understanding of the notion of region can be expanded in terms of its adaptation to social, legal, and economic needs.

As an underlying element of the national economy, a region is a territorial unit of a country's economic space in which the economic reproduction process is carried out. Although different regions have distinguishing features, they all share the objective laws of economic reproduction. This is due to the fact that marketplaces represent the major portion of regional assets and act as holders of special regional interests. They serve to implement the principle of regional self-sufficiency in economic reproduction. At the same time, different regions have different levels of social and economic development, which means that they deal with different issues of economic reproduction.

The intensity of resource use also varies. The world's population has doubled since 1970, entailing a threefold increase in material resources and a twofold increase in GDP. During the same period, there was no long-term stability or decline in global resources consumption. The relationship between economic growth and the environment was not detected either. The extraction and processing of natural resources have intensified since 2000, accounting for approximately $90 \%$ of water footprint and biodiversity loss and for almost half of the climate impacts.

The scientific ground for reflecting the process of economic reproduction in the region involves various aspects of regional economic development. In this case, the focus can be on these resource categories: natural resources, territorial resources, political resources, economic resources, production resources, tangible resources, transport and infrastructure, social ethnicity, and nationality. Factors that affect economic potential in regions are:

- the quantity of resources: working-age population, skilled manpower, financial resources, and natural resources;

- the economic quality of resources: the size and sectoral composition of the regional economy, the cost of production assets, commodity market maturity, and level of income;

- infrastructure: communication and information networks, institutions and marketing organizations, including banks, stock exchanges, and insurance companies;

- innovation: R\&D efforts, technology adoption, and operation of intellectual companies, R\&D institutes, and corporate sponsorship funds;

- external influences: macroeconomic indicators and national development programs adapted with respect to regional economic and tax policies.

Among these factors, resources are the most important one. They represent an attribute and potential of the territory. Resources include non-temporal elements, such as labor, land, and capital, and resource potential is a basis for regional differentiation. The quantity and quality of resources, as well as resource efficiency, have a decisive impact on the pace of social and economic development in the region. Resources may come from within the region (internal resources) or from other regions (external resources). At the same 
time, the character of any economic process and market crisis (cyclical fluctuations in stock prices and exchange rates) is cyclical.

Other factors can also be considered as external and internal changes in a business environment, where external changes are federal restrictions, and internal changes are infrastructure and innovation enterprises operating in the region, as well as local tax legislation and guarantees.

An important element in reproduction management is regional typology. There are many kinds of factors that can be used to generate a typology, each of which somewhat reflects a variety of issues that surround the regional reproduction process and the role it plays in overall production. Sharafutdinov et al. (2019) proposed to use an inclusive growth index to categorize economic regions. Trukhachev and Gromov (2016) differentiated rural areas depending on their levels of development. Mayorova et al. (2018) focused on trade activity. It appears that a choice of research methodology for regional differentiation of Russia depends on the researcher's objectives. The present study builds a typology of Russia's economic regions based on a criterion of GRP (Table 1). The aim is to identify the promising directions of the federal investment policy. The main idea of the economic zones theory in this context is that a proper regional division will enable effective governance and comprehensive development of regions.

Table 1: Regions of Russia by GDP, adapted from (Federal State Statistics Service, 2019)

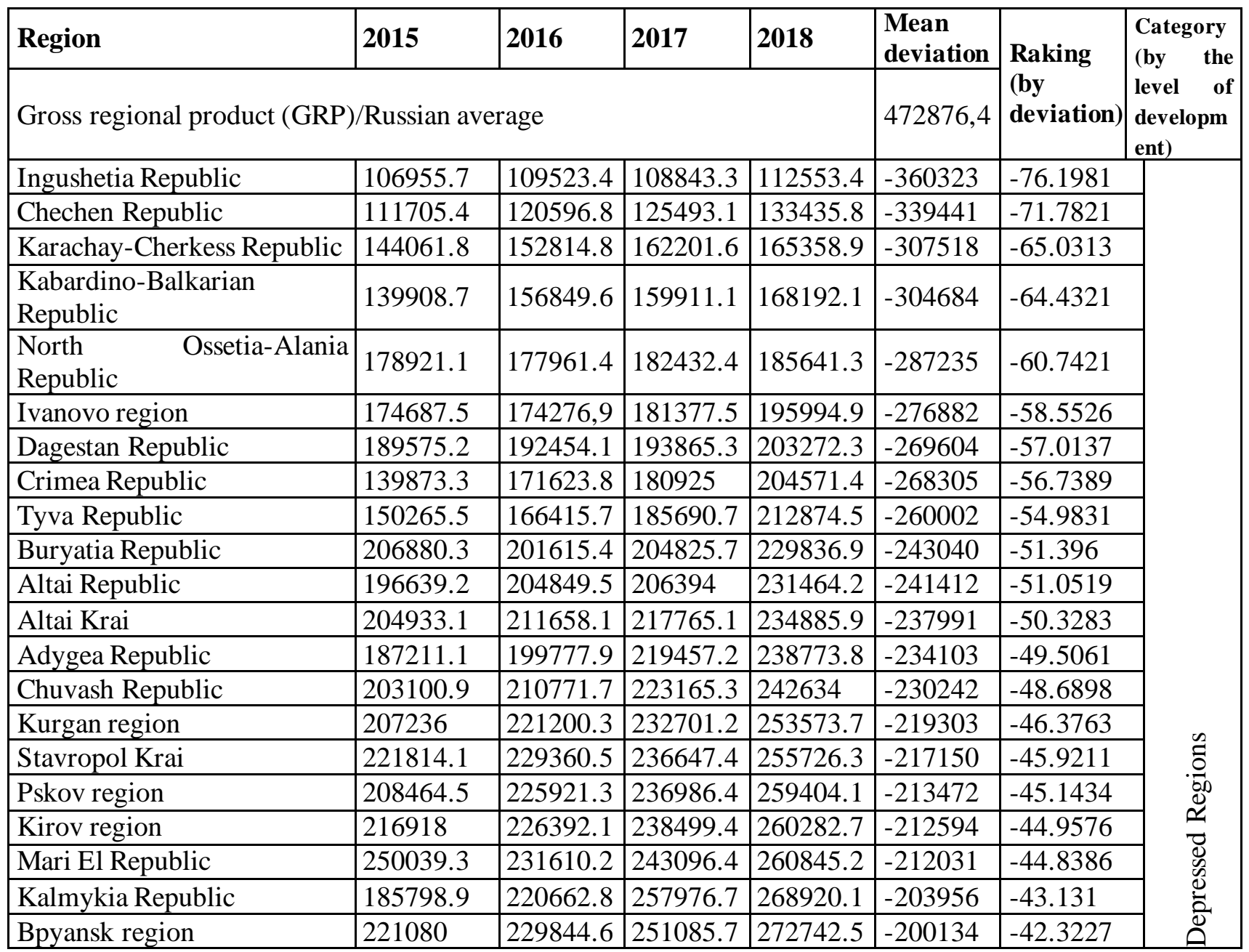


ISSN: 2247-6172

Review of Applied Socio- Economic Research

(Volume 22, Issue 2/ 2021), pp. 128 - 141

URL: http://www.reaser.eu e-mail: editors@ @reaser.eu

\begin{tabular}{|c|c|c|c|c|c|c|c|}
\hline Ulyanovsk region & 241633.8 & 259138.2 & 266860 & 279959.2 & -192917 & -40.7965 & \\
\hline Kostroma region & 245940.9 & 243346.4 & 258533 & 281568.6 & -191308 & -40.4562 & \\
\hline Republic of Mordovia & 223161.1 & 249649 & 266917.6 & 284010.1 & -188866 & -39.9399 & \\
\hline Saratov region & 251047.1 & 258970.2 & 270564.3 & 290611.6 & -182265 & \begin{tabular}{|l|}
-38.5439 \\
\end{tabular} & \\
\hline Penza region & 253911 & 259365.9 & 274369.4 & 302304.4 & \begin{tabular}{|l}
-170572 \\
\end{tabular} & -36.0712 & \\
\hline Trans-Baikal Krai & 228215 & 256337.7 & 279814.3 & 305683.1 & -167193 & -35.3567 & \\
\hline Oryol region & 273107.5 & 284385.8 & 286468 & 310357.1 & -162519 & -34.3682 & \\
\hline Vladimir region & 262945.5 & 282603.6 & 298375.9 & 321078.9 & -151798 & \begin{tabular}{|l|}
-321009 \\
\end{tabular} & \\
\hline Tambov region & 300289.9 & 284834.1 & 288147.3 & 323618.7 & -149258 & -31.5638 & \\
\hline Smolensk region & 266927.2 & 275444.3 & 306413.8 & 330766 & -142110 & -30.0523 & \\
\hline Volgograd region & 290186 & 293947.7 & 305597.8 & 338860.7 & -134016 & -28.3405 & \\
\hline Ryazan region & 285257.8 & 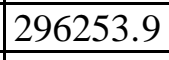 & 321083.3 & 342734.4 & -130142 & \begin{tabular}{|l|}
-27.5214 \\
\end{tabular} & \\
\hline Rostov region & 280522 & 303222.9 & 320007.8 & 343408.7 & \begin{tabular}{|l}
-129468 \\
\end{tabular} & \begin{tabular}{|l|}
-27.3788 \\
\end{tabular} & \\
\hline Tver region & 251633.2 & 277929.2 & 300328.7 & 345919.1 & -126957 & -26.8479 & \\
\hline Jewish Autonomous Region & 266405.8 & 278590.6 & 323376.9 & 346715.8 & -126161 & -26.6794 & \\
\hline Omsk region & 312450.2 & 314593.5 & 33071.3 & 349165.7 & -123711 & -26.1613 & \\
\hline Amur region & 343385.7 & 337302.1 & 338055.7 & 378318.7 & -94557.7 & -19.9963 & \\
\hline Kursk region & 301242.5 & 323145.8 & 346101.2 & 385587.5 & -87288.9 & -18.4591 & \\
\hline Voronezh region & 345566.8 & 350097.6 & 371924.5 & 404838.5 & -68037.9 & -14.3881 & \\
\hline Bashkortostan Republic & 323367.4 & 328820.8 & 346902.2 & 412530 & -60346.4 & $-12,7616$ & \\
\hline Krasnodar Krai & 352601.2 & 374677.7 & 398693.9 & 416760.2 & -56116.2 & \begin{tabular}{|l|}
-11.867 \\
\end{tabular} & \\
\hline Udmurt Republic & 341391.7 & 350598.3 & 364572.4 & 417899.1 & -54977.3 & -11.6261 & \\
\hline Chelyabinsk region & 345597.1 & 363023.3 & 386862.1 & 422950.8 & -49925.6 & -10.5579 & \\
\hline Nizhny Novgorod region & 338304.4 & 356725.8 & 389339.4 & 424085.8 & -48790.6 & -10.3178 & \\
\hline Tula region & 316248.5 & 345117.1 & 372264.9 & 428275.7 & -44600.7 & -9.43179 & \\
\hline Novgorod region & 379255.5 & 396336.2 & 414521.2 & 434229.5 & -38646.9 & -8.17273 & \\
\hline Primorsky Krai & 371595.6 & 383811.3 & 404747.6 & 437147.4 & -35729 & -7.55567 & \\
\hline Khakassia Republic & 317763.6 & 365436.6 & 386039.4 & 438326 & -34550.4 & -7.30643 & \\
\hline Yaroslavl region & 348375.7 & 371537 & 403037.8 & 443970.1 & -28906.3 & -6.11287 & \\
\hline Novosibirsk region & 370895.7 & 377812.4 & 412480 & 448658.8 & -24217.6 & -5.12134 & \\
\hline Karelia Republic & 335944.5 & 368250.2 & 403076.5 & 451436.4 & -21440 & -4.53395 & \\
\hline Kaluga region & 336353.9 & \begin{tabular}{|l|}
367867.8 \\
\end{tabular} & 4410481.4 & 461023.2 & -11853.2 & -2.50662 & \\
\hline Kaliningrad region & 359639.7 & 392825.3 & 421319.1 & 461596.7 & -11279.7 & -2.38534 & \\
\hline Kemerovo region & 309904.3 & 318927.5 & 391741.4 & 462495.1 & -10381.3 & -2.19535 & \\
\hline Samara region & 394135.9 & 396379 & \begin{tabular}{|l|l|}
421777.2 \\
\end{tabular} & 473772.9 & 896.4975 & \begin{tabular}{|l|}
0.189584 \\
\end{tabular} & \multirow{12}{*}{ 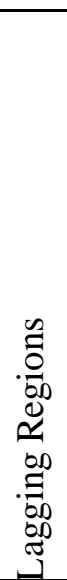 } \\
\hline Vologoda region & 402652.1 & 402455.1 & 431059 & 497039.6 & 24163.2 & 5.109834 & \\
\hline Permsky Krai & 403601.4 & 416203.6 & 453431.5 & 503818.3 & 30941.9 & 6.543337 & \\
\hline Lipetsk region & 388074.7 & 418328.4 & 439070.1 & 506054.3 & 33177.9 & 7.016188 & \\
\hline Orenburg region & 387881.4 & 384169.7 & 415322.4 & 507847.3 & 34970.9 & 7.395357 & \\
\hline Sverdlovsk region & 421100.7 & 459812.1 & 492434.2 & 527158.5 & 54282.1 & 11.47913 & \\
\hline Khabarovsk region & 445809.5 & \begin{tabular}{|l|l|}
470346.9 \\
\end{tabular} & 487222.8 & 536377.5 & 63501.1 & 13.42869 & \\
\hline Tomsk region & 438316.5 & 445485.9 & 473722.4 & 537512.2 & 64635.8 & 13.66865 & \\
\hline Astrakhan region & 315996.9 & 340398.3 & 413087.7 & 544793.4 & 71917 & 15.20841 & \\
\hline Moscow region & 437249.1 & 496848.6 & 506478.2 & 556413.9 & 83537.5 & \begin{tabular}{|l}
17.66582 \\
\end{tabular} & \\
\hline Belgorod region & 447619.7 & 469921.6 & 506167.8 & 559184.2 & \begin{tabular}{|l|}
86307.8 \\
\end{tabular} & 18.25166 & \\
\hline Irkutsk region & 414986.5 & 442342.2 & 496425.7 & 580152.8 & 107276.4 & 22.68593 & \\
\hline
\end{tabular}


ISSN: 2247-6172

Review of Applied Socio- Economic Research

(Volume 22, Issue 2/ 2021), pp. 128 - 141

URL: http://www.reaser.eu e-mail: editors@ @reaser.eu

\begin{tabular}{|c|c|c|c|c|c|c|c|}
\hline Leningrad region & 478065.2 & 513307.8 & 534595.6 & 603239.7 & 130363.3 & 27.56815 & \\
\hline Tatarstan Republic & 483509.9 & 498606.1 & 550112.4 & 633708.5 & 160832.1 & 34.01144 & \\
\hline Murmansk region & 525475.7 & 568975.6 & 585780.9 & 642705.6 & 169829.2 & 35.91408 & \\
\hline Arkhangelsk region & 532533.7 & 581651.6 & 625656.4 & 712652.7 & 239776.3 & 50.70591 & \multirow{6}{*}{ 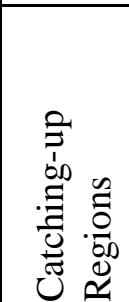 } \\
\hline Kamchatka Krai & 553863.9 & 624774.2 & 640877 & 750407.7 & 277531.3 & 58.69003 & \\
\hline Krasnoyarsk Krai & 582345.8 & 608083.3 & 660393.9 & 792980.5 & 320104.1 & 67.69297 & \\
\hline Komi Republic & 613975 & 641525 & 680670.8 & 796759.7 & 323883.3 & 68.49217 & \\
\hline Sakha (Yakutia) Republic & 780139.8 & 897460.4 & 951330 & 1123114 & 650237.4 & 137.5068 & \\
\hline Magadan Region & 854561.5 & 1016643 & 1082848 & 1196690 & 723813.7 & 153.0661 & \\
\hline $\begin{array}{ll}\text { Chukotka } & \text { Autonomous } \\
\text { Okrug } & \end{array}$ & 1226152 & 1354368 & 1376275 & 1578496 & 1105620 & 233.8073 & \multirow{3}{*}{ 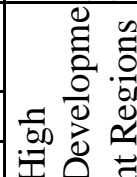 } \\
\hline Tyumen region & 1626160 & 1651996 & 1897390 & 2370552 & 1897675 & 401.3047 & \\
\hline Sakhalin region & 1716734 & 1536360 & 1573869 & 2407929 & 1935053 & 409.209 & \\
\hline
\end{tabular}

A total of 79 economic regions were divided into these four groups by the level of economic development: depressed regions (where GRP exhibits negative deviation from the Russian average); lagging regions (where GRP deviates by 50\% from the Russian average); catching-up regions (where GRP deviates by $50 \%$ to $150 \%$ from the Russian average); high development regions (where GRP deviates by $150 \%$ from the Russian average). High development and catching up regions, those with high and above-average levels of economic development, have distinct productive specializations, the highest industrial outputs, and a better quality of life. In contrast, the lagging regions, those with below-average levels of development, exhibit substantial asymmetry, yet they also show promise for growth and possess mechanisms of selfregulation and adaptation to market changes (Sorokina \& Pyankova, 2019). Depressed regions, on the other hand, struggle with significant deficits in resources and thus cannot attract additional investments. To improve their economic situation, these regions seek state assistance and develop industries that can generate more profits in less time.

Each economic region is governed by the subsidiarity principle. Such regional type requires the coordination of municipalities using statistical research, economic analysis, forecasting, and monitoring operations. The level of resource security is inextricably linked to the cyclicality of economic development. In high development and catching-up regions, resource allocation is carried out in a manner that allows achieving a higher level of development. At the same time, the attraction of resources to the region cannot last forever because regions obey the laws of socio-economic development. Reviewing studies by Rau et al. (2018) and Kuklina and Lazareva (2017), we analyzed the process of regional development with respect to life cycle stages and the quantity of resources involved. The results are shown in Figure 1. 


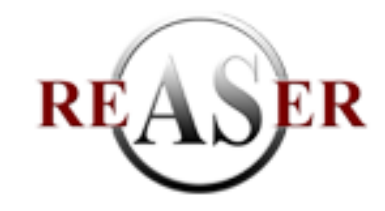

ISSN: 2247-6172

Review of Applied Socio- Economic Research

(Volume 22, Issue 2/ 2021), pp. 128 - 141

URL: http://www.reaser.eu e-mail: editors@reaser.eu

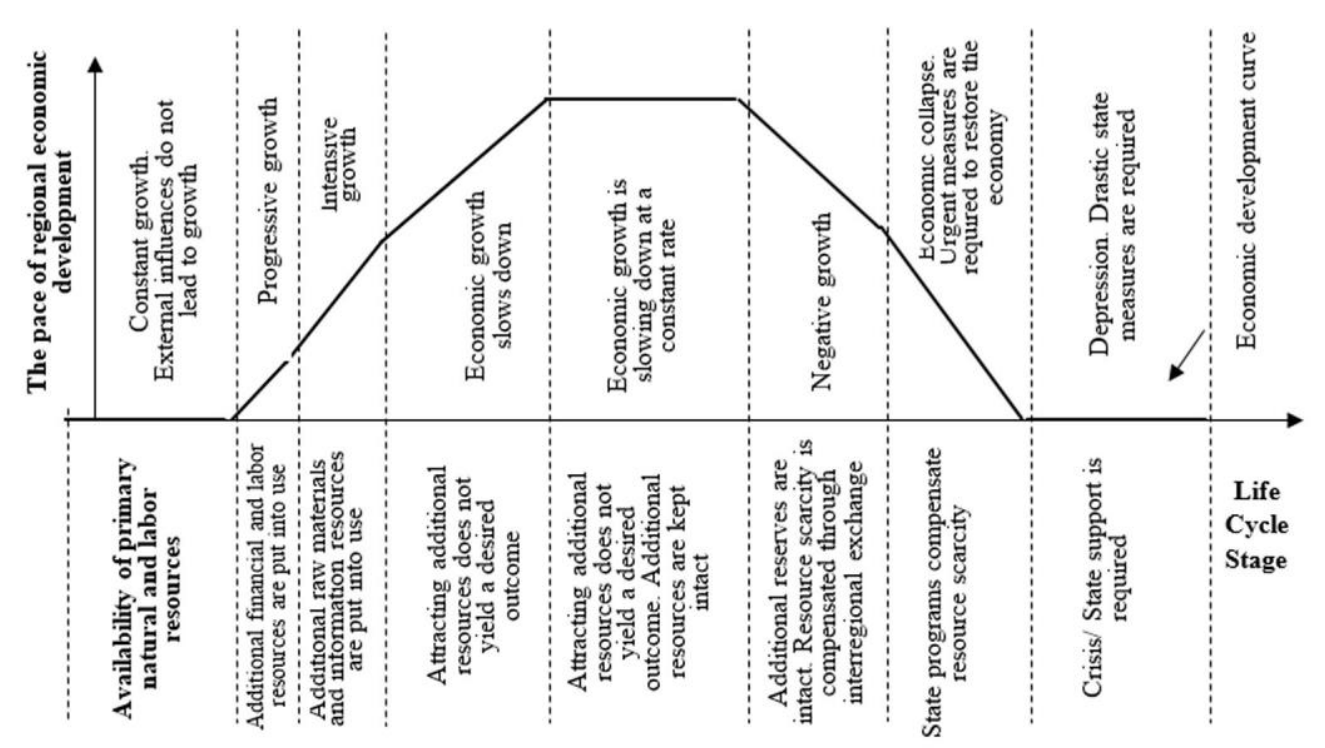

Fig. 1: Factors influencing regional economic development and measures of state regulation, developed by the authors.

Economic growth and economic development require resources, which are neither infinite nor totally interchangeable. This creates barriers to growth, and any intensification of production along with greater consumption may entail resource scarcity. Hence, the faster the region grows, the more likely it will run out of resources, especially if it represents a closed or semi-closed system. At the same time, resources cannot all be depleted at once - they will become limited at some point, and before the shortage can be considered critical, the amount of resources must be reduced to the point that exchangeable resources cannot be stabilized.

There is a minimum quantity of resources required for each region to function and develop effectively. The beginning of the economic cycle is characterized by the sufficient quantity and diversity of resources (Figure 1). The fourth stage of development is characterized by slower economic growth, a situation in which a region may face a challenge of excess resources if it does not rein in its appetite (Pyankova \& Sorokina, 2019). Industries have resource requirements that align with their business operations. However, due to the fundamental limitations of the resource base, eventually, at some point in time, markets will be oversaturated with resources, and the region's growth rate will outstrip the growth rate of the resource base.

In general, the resource base fails to keep up with the pace of economic growth due to substantial inertia in technology adoption and greater time demands. The sixth and seventh stages of development provide opportunities to replenish the resources through international exchange, but this source is not always in place, especially when the level of economic development is high. When a region encounters a crisis, it can achieve balance by turning to neighboring regions and international parties, but if the crisis takes place on a global scale, this solution can no longer be an option. The eighth stage of development requires the unconditional state regulation of the regional economy in order to mitigate external threats to the regional resource reserves that may further weaken the economy.

From the discussion above, it appears that regional economic development is cyclical in nature and can be defined through the ratio of resources that fuel economic development. In other words, there is an optimal set of resources required for each region to run their economies without disruptions and achieve effective outcomes. To determine the content of this particular set of resources, the limit for resources in the region 
ISSN: 2247-6172

Review of Applied Socio- Economic Research

(Volume 22, Issue 2/ 2021), pp. 128 - 141

URL: http://www.reaser.eu

e-mail: editors@ @reaser.eu

was determined. In this study, the limit for resources refers to the limited range and quantity of resources available for a specific time-bound duration that allow achieving a higher level of development without critical side effects in the long term.

The resulting estimate of the region's resource availability can be considered as an objective outcome forecast for economic development and resource management operations. This approach focuses on the following variables (Table 2): GRP (dependent variable), employment-to-population (E-to-P) ratio, budgetary capacity, natural resource potential, the fixed assets volume, the number of public libraries, newspaper circulation (total papers per 1000 people), and broadcast coverage. These variables (factors) allow building a model to calculate the minimum volume of resources required for a region to be sustainable.

Table 2: Factors affecting resource availability in regions, developed by the authors

\begin{tabular}{|c|c|c|c|}
\hline Factor & Description & $\begin{array}{l}\text { Impact on Dependent } \\
\text { Variable }\end{array}$ & Limitations \\
\hline $\begin{array}{l}\text { Gross Regional } \\
\text { Product (GDP) }\end{array}$ & $\begin{array}{l}\text { A dependent variable that } \\
\text { measures the total market } \\
\text { value of the goods and } \\
\text { services produced by s } \\
\text { regional economy during a } \\
\text { specified period of time }\end{array}$ & $\begin{array}{l}\text { Allows intensifying areas of } \\
\text { improvement }\end{array}$ & $\begin{array}{l}\text { The GRP estimate is also } \\
\text { influenced by other factors } \\
\text { that were not included in } \\
\text { the present study. }\end{array}$ \\
\hline $\begin{array}{l}\text { Employment- } \\
\text { to-Population } \\
\text { (E-to-P) Ratio }\end{array}$ & $\begin{array}{l}\text { An independent variable } \\
\text { that measures the number } \\
\text { of people employed against } \\
\text { the total working-age } \\
\text { population }\end{array}$ & $\begin{array}{l}\text { Allows determining the } \\
\text { extent to which the labor } \\
\text { force affects the GRP value }\end{array}$ & $\begin{array}{l}\text { More detailed analysis is } \\
\text { needed to include the share } \\
\text { of the self-employed } \\
\text { population and employed } \\
\text { volunteers. }\end{array}$ \\
\hline $\begin{array}{l}\text { Budgetary } \\
\text { Capacity }\end{array}$ & $\begin{array}{l}\text { An independent variable } \\
\text { that measures the } \\
\text { availability of financial } \\
\text { resources in a region }\end{array}$ & $\begin{array}{l}\text { Allows establishing whether } \\
\text { there is budget depletion and } \\
\text { identifying strategic } \\
\text { directions for the budget } \\
\text { overrun }\end{array}$ & $\begin{array}{l}\text { Due to the increase in the } \\
\text { number of resource- } \\
\text { deficient regions, } \\
\text { additional measures of } \\
\text { financial and budgetary } \\
\text { regulation are required. }\end{array}$ \\
\hline $\begin{array}{l}\text { Natural } \\
\text { Resource } \\
\text { Potential }\end{array}$ & $\begin{array}{l}\text { An independent variable } \\
\text { that measures the } \\
\text { availability of natural } \\
\text { (renewable and non- } \\
\text { renewable) resources in a } \\
\text { region }\end{array}$ & $\begin{array}{l}\text { Allows identifying available } \\
\text { natural resources, } \\
\text { determining regional } \\
\text { specialization, and detecting } \\
\text { growth opportunities }\end{array}$ & $\begin{array}{l}\text { An immediate response to } \\
\text { changes in the natural } \\
\text { resource potential is hardly } \\
\text { possible. }\end{array}$ \\
\hline $\begin{array}{l}\text { Fixed Assets } \\
\text { Volume }\end{array}$ & $\begin{array}{l}\text { An independent variable } \\
\text { that measures the } \\
\text { availability of raw materials } \\
\text { and industrial resources in a } \\
\text { region }\end{array}$ & $\begin{array}{l}\text { Allows establishing the } \\
\text { relationship between } \\
\text { economic growth and } \\
\text { industrial waste utilization }\end{array}$ & $\begin{array}{l}\text { The availability of waste } \\
\text { utilization services heavily } \\
\text { depends on the state } \\
\text { regulatory policy. It is not } \\
\text { possible to enhance waste } \\
\text { utilization immediately. }\end{array}$ \\
\hline $\begin{array}{l}\text { Number of } \\
\text { Public } \\
\text { Libraries }\end{array}$ & \multirow{2}{*}{$\begin{array}{l}\text { Independent variable that } \\
\text { measures the availability of } \\
\text { information resources in a } \\
\text { region }\end{array}$} & \multirow{2}{*}{$\begin{array}{l}\text { Allows measuring the level } \\
\text { of information awareness } \\
\text { among citizens, as well as } \\
\text { the intensity and speed of } \\
\text { information dissemination, }\end{array}$} & $\begin{array}{l}\text { Public libraries demand } \\
\text { state funding }\end{array}$ \\
\hline $\begin{array}{l}\text { Newspaper } \\
\text { Circulation }\end{array}$ & & & $\begin{array}{l}\text { Newspapers have low } \\
\text { coverage }\end{array}$ \\
\hline
\end{tabular}




\begin{tabular}{|l|l|l|l|}
\hline $\begin{array}{l}\text { Broadcast } \\
\text { Coverage }\end{array}$ & $\begin{array}{l}\text { the completeness of the } \\
\text { information provided, and } \\
\text { information coverage }\end{array}$ & $\begin{array}{l}\text { Media content undergoes } \\
\text { filtering }\end{array}$ \\
\hline
\end{tabular}

In real-life economic conditions, the relationship between the examined factors is typically non-linear. The easiest way to present data in this context is to apply a factorial polynomial to the approximated dependent variable. In this case, we assume that there is a linear relationship between the dependent variable and the independent variable. The polynomial model will thus have the following form:

$$
Y=f(x)+\varphi
$$

where: $\varphi$ is a random variable that represents an external influence; $f(x)$ is a dependence function; $x$ is the input or the independent variable; and $Y$ is the output or the dependent variable.

Before building a model of state regulation, it is necessary to determine the limit on the quantity of resources required for each region to keep up. Another crucial step in state regulation modeling is the development of mechanisms to boost the effectiveness of entities that run their operations in those regions. For this, selecting a set of regulatory instruments should be based on regional specialization, territorial affiliation, primary resources availability, and their intensity. This technology is based on the analysis of primary and secondary resources that enable to foresee the region's capacity for self-development and identify strategic areas of development. Hence, it can be considered as a tool that helps to achieve more balanced regional development.

The GRP-based analysis revealed regions with varying levels of resource scarcity (Table 1). Of those, the following regions or federal subjects were selected for further analysis (Table 3): the Republic of Ingushetia, the Oryol region, the Kemerovo region, the Samara region, the Moscow region, the Murmansk region, the Arkhangelsk region, the Komi Republic, the Magadan region, the Chukotka Autonomous Okrug, and the Sakhalin region.

Table 3: Input data for regression analysis, adapted from (Federal State Statistics Service, 2019)

\begin{tabular}{|c|c|c|c|c|c|c|c|c|}
\hline \multirow{2}{*}{ Region/Factor } & GDP & $\begin{array}{l}\text { E-to-P } \\
\text { Ratio }\end{array}$ & $\begin{array}{l}\text { Budgetary } \\
\text { Capacity }\end{array}$ & $\begin{array}{l}\text { Natural } \\
\text { Resource } \\
\text { Potential }\end{array}$ & $\begin{array}{l}\text { Working } \\
\text { Resource } \\
\text { Reserve } \\
\text { Volume }\end{array}$ & $\begin{array}{l}\text { Number } \\
\text { of Public } \\
\text { Libraries }\end{array}$ & $\begin{array}{l}\text { Newspaper } \\
\text { Circulation }\end{array}$ & $\begin{array}{l}\text { Broadcast } \\
\text { Coverage }\end{array}$ \\
\hline & Y & $\mathbf{x 1}$ & $\mathbf{x} 2$ & $\mathrm{x} 3$ & $\mathrm{x} 4$ & $\times 5$ & x6 & $\times 7$ \\
\hline $\begin{array}{l}\text { Republic of } \\
\text { Ingushetia }\end{array}$ & 112553 & 53.7 & 19728.6 & 90.6 & 138700 & 1348 & 22 & 6 \\
\hline Oryol region & 310357 & 55 & 14080.7 & 93 & 522013 & 6337 & 592 & 178.3 \\
\hline Kemerovo region & 462495 & 56.1 & 21772 & 10.6 & 2738986 & 5043 & 623 & 488.2 \\
\hline Samara region & 473772 & 61.5 & 21499.9 & 83.2 & 3479558 & 4313 & 1179 & 698.6 \\
\hline Moscow region & 556414 & 65 & 51905 & 145.4 & 8981281 & 2692 & 506 & 1555.3 \\
\hline Murmansk region & 642706 & 63.2 & 8955.6 & 200 & 2043500 & 7674 & 540 & 215.3 \\
\hline $\begin{array}{l}\text { Arkhangelsk } \\
\text { region }\end{array}$ & 712653 & 56.2 & 19492.9 & 67.6 & 1392744 & 6869 & 2366 & 261 \\
\hline
\end{tabular}


ISSN: 2247-6172

Review of Applied Socio- Economic Research

(Volume 22, Issue 2/ 2021), pp. 128 - 141

URL: http://www.reaser.eu e-mail: editors@ @reaser.eu

\begin{tabular}{|l|l|l|l|l|l|l|l|l|}
\hline Komi Republic & 796760 & 59.4 & 8869 & 136 & 3359325 & 7800 & 1097 & 198.4 \\
\hline Magadan region & 1196690 & 69.7 & 9477.7 & 82.5 & 1168547 & 11838 & 327 & 33.4 \\
\hline $\begin{array}{l}\text { Chukotka } \\
\begin{array}{l}\text { Autonomous } \\
\text { Okrug }\end{array}\end{array}$ & & & & & & & \\
\hline Sakhalin region & 2407929 & 65.8 & 5409.9 & 56.2 & 347962 & 6157 & 311 & 95.5 \\
\hline
\end{tabular}

The results of polynomial regression analysis for each regional category are summarized in Table 4 . These values dictate the priority areas of state regulation depending on the region's levels of development. It appears that $X 2$ (budgetary capacity) and $X 4$ (fixed assets volume) have the greatest impact on the level of regional economic development or GRP, denoted as $Y$. The high level of regional development is largely attributed to the generation of fixed assets.

Table 4: The results of regression analysis for each category of economic regions of Russia, developed by the author

\begin{tabular}{|l|l|}
\hline Category & Regression \\
\hline Depressed regions & $Y=576100,1+12,05 \cdot x_{1}-24,58 \cdot x_{2}-4402,13 \cdot x_{3}+0,15 \cdot x_{4}-127,96 \cdot x_{5}+225,66 \cdot x_{6}-233,66 \cdot x_{7}$ \\
\hline Lagging regions & $Y=515362,3+12,05 \cdot x_{1}-41,34 \cdot x_{2}-4402,13 \cdot x_{3}+0,24 \cdot x_{4}-127,96 \cdot x_{5}+225,66 \cdot x_{6}-233,66 \cdot x_{7}$ \\
\hline Catching-up regions & $Y=1841023+12,05 \cdot x_{1}-43,97 \cdot x_{2}-4402,13 \cdot x_{3}-0,19 \cdot x_{4}-127,96 \cdot x_{5}+225,66 \cdot x_{6}-233,66 \cdot x_{7}$ \\
\hline $\begin{array}{l}\text { High development } \\
\text { regions }\end{array}$ & $Y=576732,8+12,05 \cdot x_{1}-35,14 \cdot x_{2}-4402,13 \cdot x_{3}+5,26 \cdot x_{4}-127,96 \cdot x_{5}+225,66 \cdot x_{6}-233,66 \cdot x_{7}$ \\
\hline
\end{tabular}

The framework of state regulation (Figure 2) should include measures aimed at enhancing budgetary and financial regulation, improving material structure, and promoting employment. The reason for undertaking these measures of state regulation may be a situation where a GRP deviates from the Russian average. The present study confirms that organizational changes undertaken to impact economic growth will be effective if they align with both the direction of regional development and regional specialization. The forms of state support for initiatives or projects launched in response to organizational changes, restructuration, expansion, and creation of new industries, can vary.

The financial regulation framework can involve these instruments of state support: sponsorship, interbudgetary transfers, grants, and subsidies, including equity funding, government guarantees, and budgeting loans. The framework for material structure improvement is aimed at balancing functional and spatial development and includes measures to harmonize legislation, stimulate joint territorial development, shape a competitive environment, reduce administrative barriers, and enhance regional self-regulation. Measures to influence employment seek to redistribute resources between sectors with different levels of employment, remove the dominance of rent-oriented behavior, reduce public-sector employment (with the view to promoting the efficient use of labor), enhance labor mobility, and improve immigration attractiveness.

Way to improve resource efficiency revolve around running state research programs, stimulating R\&D in the manufacturing industry, consulting on demonstration projects, and instilling innovations. These measures will reduce resource intensity and production costs. However, a reduction of production costs has a proactive effect on increasing consumption, which will outweigh the costs in terms of resource efficiency. Moving from income and consumption taxes to resources taxes may help to counter this effect. Other 


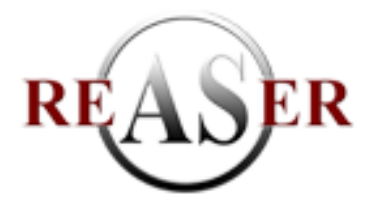

ISSN: 2247-6172

Review of Applied Socio- Economic Research

(Volume 22, Issue 2/ 2021), pp. 128 - 141

URL: http://www.reaser.eu

e-mail: editors@reaser.eu

solutions may involve changing the technical standards and procurement policies. Measures undertaken to regulate the use of natural resources and land ecosystems are designed to avoid unreasonable impacts on the environment. Carbon taxes can help to prevent deforestation by forcing land users to refrain from releasing carbon emissions. Removing biofuel subsidies will entail the reduction of competition across the country and prevent the rise of food prices.

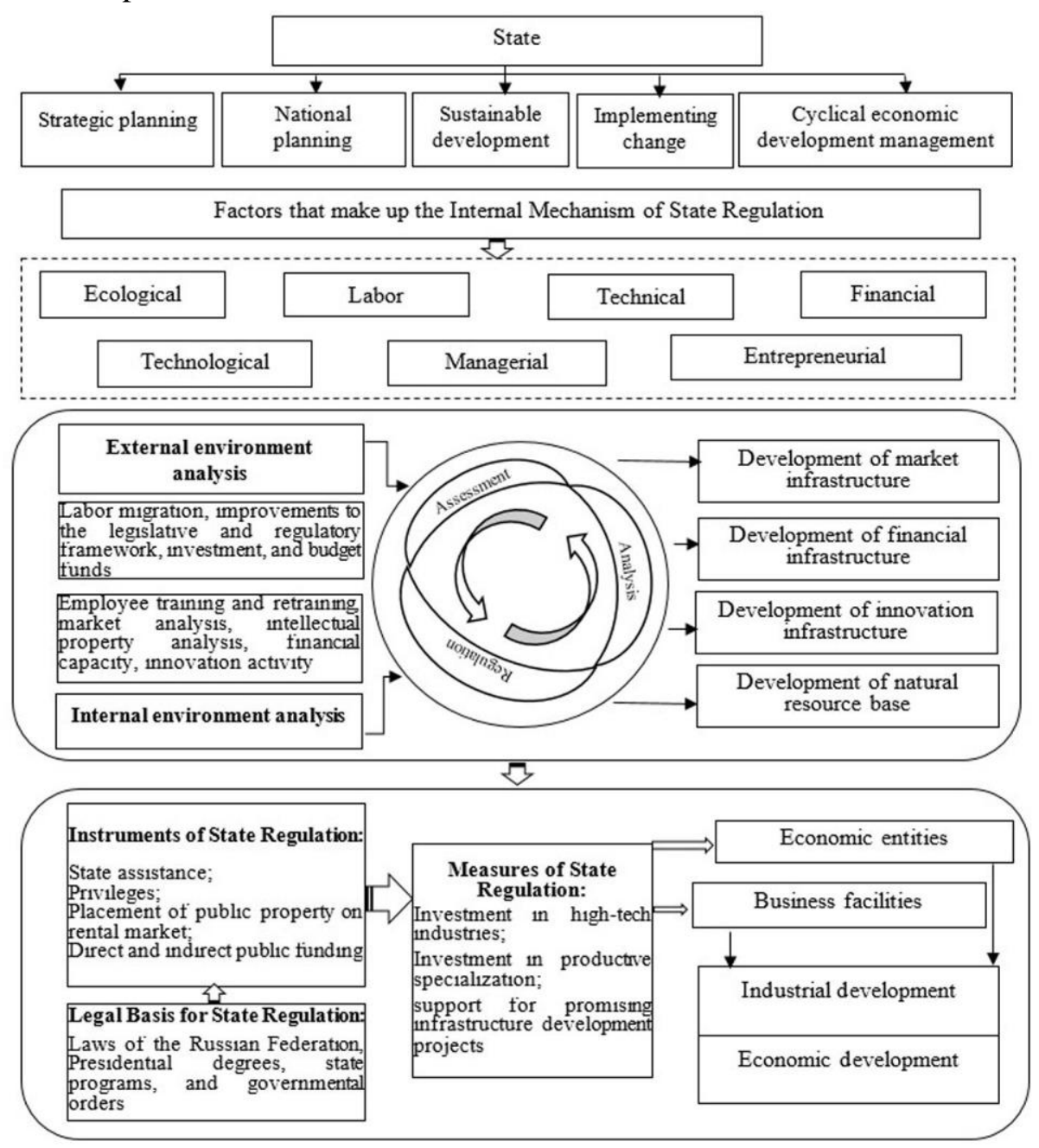

Fig. 2: The state regulation framework to minimize regional resource deficiency, developed by the author.

\section{Discussions}

Among other things, Russia's development strategy aims at the prevention of structural imbalances and economic harmonization across regions. For this, the concept of resource scarcity was introduced, which determines the process and mechanism of providing the region with resources with the view of achieving the highest efficiency possible.

There are many other indicators besides GRP to analyze regional economic performance. Nasir et al. (2017) measured the potential of local taxes as a source that boosts the original local income, affecting the society and neighboring areas. Zinovyeva et al. (2020) formulated and confirmed a hypothesis that during the 
crisis, one should consider economic growth as a tool to manage and reach short-term goals rather than a goal in itself. The volume of innovation financing was regarded as a dependent variable.

The present state regulatory framework for the regional economy (Figure 2) is not limited to the proposed range of instruments and measures. Fabbri et al. (2020) developed a regional resource model in continuous time and identified approaches to counteract the overexploitation of resources through regulating the technological parameters of impact on exploitation. Basu et al. (2020) took microfinance in the household sector as a key instrument of regional development regulation. The analysis was based on statistical data concerning household income, household spending, and capital turnover. Findings revealed a relationship between loan amount and levels of monthly household income, household expenditure, and household savings. Zvyagintseva et al. (2016) devoted their study to the assessment and improvement of the state regulation toolkit using regional development potential and modeled a number of development scenarios with regard to available resources.

To sum up, the existing research into the regional-level resource availability largely concentrates on analyzing or forecasting economic growth and developing instruments of state support. The state regulatory framework proposed in the present study takes into account the full range of regional resources and makes it possible to choose the most effective tools of state support.

\section{Conclusions}

Regional resource scarcity is a constraining factor in achieving better performance. At the same time, it is closely related to the concept of regional resource availability. The present work substantiates the need for using the concept of regional resource availability to analyze regional performance and develop measures of state support. The need for state support arises when the level of regional development deviates from the established 'ideal' level, and the aim of state support is to prevent further deviation.

The assessment of the regional economic development involves regional differentiation by regional GDP estimates, and the average GRP value across regions was taken as an 'ideal' value. All regions were thus divided into four groups: depressed regions (where GRP exhibits negative deviation), lagging regions (those with a below-average level of development), catching-up regions (those with an above-average level of development), and high development regions. Note that regional resource availability varies between regions depending on territorial affiliation, regional specialization, and the life cycle stage. For this reason, it is necessary to consider individual characteristics of regional development and possibilities for expanding their resource availability. For this, factor analysis was carried out, and the results revealed dependencies of economic development for each category of regions.

The study proposes a set of state support measures with the view to expanding the resource availability of regions with varying levels of economic development. Most attention is given to capital resources, information resources, human resources, and raw materials. However, it appears that state support cannot be established to expand primary natural resources. The region can improve the availability of this type of resource by enhancing environmental protection and pollution control.

Future research will focus on subdividing regions within each category by their territorial affiliation and identifying factors that have a boosting effect on economic growth and development. With this information, the proposed state regulatory framework can be adjusted, and each region will receive a specially designed set of state regulation measures. 
ISSN: 2247-6172

Review of Applied Socio- Economic Research

(Volume 22, Issue 2/ 2021),pp. 128 - 141

URL: http://www.reaser.eu e-mail: editors@ @reaser.eu

\section{Acknowledgments}

This research did not receive any specific grant from funding agencies in the public, commercial, or not for-profit sectors. The author declares that they have no competing interests.

\section{References}

[1] Abrosimova, O. N., Burakova, M. A. (2021). Scaling of the granulation process in the conditions of GMP train ing center and assessment of possible risks. Drug Development \& Registration, 10(3), 131-137. doi: 10.33380/2305 2066-2021-10-3-131-137

[2] Basu, S., Roy, A., \& Karmokar, S. (2020). Effectiveness of microfinance on household income generation strategy in the southwestregion of Bangladesh. Asian Journal of Social Sciences and Legal Stu die s, 2(3), 56 -62. doi: 10.34104/ajssls.020.056062

[3] da Silva, A. P. T., de Medeiros, P. M., Júnior, W. S. F., \& da Silva, R. R. V. (2018). Does forest scarcity affect the collection and use of firewood by rural communities? A case study in the Atla ntic Forest of Northeastern B razil. Economic Botany, 72(1), 71-80. doi: 10.1007/s1 2231-018-9403-9

[4] Fabbri, G., Faggian, S., \& Freni, G. (2020). Policy effectiveness in spatial resource wars: A two-region model. Journal of Economic Dynamics and Control, 111, 1038 18. doi: 10.1016/j.jedc.2019.103818

[5] FederalState Statistics Service. (2019). Statistical Yearbook of the Federal State Statistic s Service. Re gions of Russia. Socio-economic indicators. https://rosstat.gov.ru/storage/mediabank/1dJJCOvT/Region Pokaz 2019.pdf (accessed 16 April 2021).

[6] Koliousis, I. G., Papadimitriou, S., Riza, E., Stavroulakis, P. J., \& Tsioumas, V. (2018). Scarcity theory and maritime clusters: From paradox to modelling. Marine Polic, 93,40-46. doi: 10.1016/j.marpol.2018.03.029

[7] Kuklina, N. S., \& Lazareva,I.E. (2017). Management laws and concepts of theirimplementation a s a source of management theory development. In Science: The Pa st, the Present, the Future (pp. 87-92). Ufa: Aeterna.

[8] Mayorova, A. N., Panasenko, S. V., Nikishin, A. F., Ivanov, G. G., \& Mayorova, E. A. (2018). Analyzing regional differences in the condition and development of trade in Russia. Entrepreneurship and Sustainability Issues, 6(2), 927. doi: 10.9770/jesi.2018.6.2(30)

[9] Murshed, S. B., \& Kaluarachchi, J. J. (2018). Scarcity of fresh water resources in the Ganges Delta of Bangladesh. Water Security, 4, 8-18. doi: 10.1016/j.wasec.2018.11.002

[10]Nasir, A., Ba sri, Y. M., Ka maliah, K., \& Muda, I. (2017). Effectiveness of potential tax region as the re al local revenue sources in Riau Coastal Area. International Journal of Economics and Research, 14(12), 313-324.

[11] Odhiambo, G. O. (2017). Water scarcity in the Arabian Peninsula and socio-economic implications. Applied Water Science, 7(5), 2479-2492. doi: 10.1007/s13201-016-0440-1

[12]Py ankova, S. G., \& Sorokina,E. (2019). Methodological a pproaches to managing investment attractiveness of a resource-deficient region: National and international ex perience. Financial economics, 6(1), 52-56.

[13]Rau, V. G., Kislyakov, A. N., Tikhonyuk, N. E., \& Rau, T. F. (2018). The principle of symmetry breaking in models of economic systems development. In Regional Economy: Experience and Challenges. Vladimir branch of the federal state budgetary educational institution of higher education "Russian Aca demy of Na tio nal Eco nomy and Public Administration under the President of the Russian Federation"(pp. 201-211). Vla dimir.

[14]Sharafutdinov, R. I., Akhmetshin, E. M., Polya kova, A. G., Gera simov, V. O., Shpakova, R. N., \& Mikhailova, M. V. (2019). Inclusive growth: Adataset on key and institutional foundations for inclusive development of Ru ssian regions. Data in Brief, 23, 103864. doi: 10.1016/j.dib.2019.103864 
[15] Shohin, I.E., Bagaeva, N. S., Mala shenko, E. A., \& Kuzina, V. N. (2020). Method of estimating the equivalence of dissolution profiles: A modern view (review). Drug Development \& Registration, 9(2), 145-150. doi: $10.33380 / 2305-2066-2020-9-2-145-150$

[16]Skokov, R. Y. (2020). Digital instruments of state regulation of a ddictive goods regional markets. Ka zan Economic Bulletin, 1(45), 100-101.

[17]Sorokina, E., \& Pyankova, S. G. (2019). Development mechanism of in vestment at tractiveness of resource deficient regions. Fundamental Research, 6, 137-141.

[18]Soula, R., Chebil, A., McCann, L., \& Majdoub, R.(2021). Water scarcity in the Mahdia re gion of Tu nisia: Are improved water policies needed? Groundwater for Sustainable Development, 12, 100510. doi: 10.1016/j.gsd.2020.100510

[19] Ta mov, A., Kha tukay, S., Mokrushin, A., \& Babalyan, E. (2020). The innovative instruments for implementing the strategy of social and economic development of the depressed region. In 8th International conference on contemporary problems in the development of economic, financial and credit systems (DEFCS 2020) (pp. 250256). Amsterdam: Atla ntis Press.

[20]Tiutiunyk, I. V. (2018). Determination of priority financial instruments of regional su stainable development. International Journal of Ecology \& Development, 33(3), 11-18.

[21] Trukhachev, V.I., \& Gromov, E. I. (2016). Assessment of a level of development of therural territories in terms of regions of Russia. Economics of Agriculture of Russia, 4, 57-65.

[22]Xinchun, C., Mengyang, W., Xiangping, G., Yalian, Z., Yan, G., Nan, W., \& Weiguang, W. (2017). Assessing water sca rcity in agricultural production system based on the generalized water resources a nd wa ter footprint framework. Science of the TotalEnvironment, 609, 587-597.doi: 10.1016/j.scitotenv.2017.07.191

[23]Zinovyeva, I. S., Savin, A. G., Brizhak, O. V., \& Shchinova, R. A. (2020). Na tural management of a m odern region: Assessment of effectiveness and perspectives of improvement. In Growth Poles of the Global Ec onomy: Emergence, Changes and Future Perspectives (pp. 717-723). Cham: Springer.

[24]Zvyagintseva, O. S., Chernobai, N. B., Babkina, O. N., Kenina, D. S., \& Sidorova, D. V. (2016). Ev aluation and forecasting of effectiveness of the use of region's development potential. Journal of Applied Economic s, 11 (40), 185-186.

Manuscript received: 30.06 .2021

Manuscript received in revised form: 06.10.2021

Manuscript accepted: 07.10.2021 